Published as: Kellens, W., Neutens, T., Deckers, P., Reyns, J., De Maeyer, Ph. 2012. Coastal flood risks and seasonal tourism: Analysing the effects of tourism dynamics on casualty calculations. Natural Hazards, 60 (3), pp. 1211-1229.

\title{
Coastal flood risks and seasonal tourism: analyzing the effects of tourism dynamics on casualty calculations
}

\author{
Wim Kellens ${ }^{1}$, Tijs Neutens ${ }^{2}$, Pieter Deckers ${ }^{2,3}$, Johan Reyns ${ }^{3}$, Philippe De Maeyer ${ }^{2}$ \\ ${ }^{1,2}$ Ghent University \\ Department of Geography \\ Krijgslaan 281, S8 (WE12) \\ B-9000 Gent, Belgium \\ ${ }^{3}$ Flanders Hydraulics Research \\ Berchemlei 115 \\ B-2400 Borgerhout, Belgium \\ ${ }^{1}$ Corresponding author \\ email:wim.kellens@ugent.be \\ tel: +3292644696 \\ fax: +3292644985
}

\begin{abstract}
Since coastal tourism is one of the fastest growing sectors of tourism industry, coastal areas have become increasingly vulnerable in case of flooding. While in recent years a number of different methods have been put forward to map coastal flood risks, the implications of tourism dynamics for the assessment of human casualties has remained largely overlooked in these models. This chapter examines to what extent the ignorance of (residential) coastal tourism may bias the calculations of human casualties. To this end, a case study has been conducted on the Belgian coast. Both the dynamic nature of coastal tourism and the behaviour of residential tourists in storm surge scenarios are considered. The results of this study show that including tourism dynamics in flood risk management is justified and appropriate, depending on the tourist attractiveness of the flood-prone area and its temporal fluctuations.
\end{abstract}

Keywords: coastal flood risks, flood casualties, tourism dynamics, tourist behaviour, GIS 


\section{Introduction}

Coastal tourism is widely regarded as one of the fastest growing areas of the world's tourism industry (Miller 1993; Hall 2001). All over the world, coastal areas are developing rapidly and are attracting more and more tourists each year. The harmful impacts of coastal tourism on coastal environments have been discussed in depth in the academic literature (Bellan and Bellan-Santini 2001). In a case study on the Turkish coast, Burak et al. (2004), for example, highlighted issues such as salinisation of the coastal aquifers due to overexploitation and loss of agricultural land due to multi-storey buildings along the shoreline. However, the growth of the coastal tourism industry also generates new challenges in the context of climate change, sea level rise and flood risks: the more tourists in a coastal area, the higher the adverse consequences of a coastal flood. Coastal tourism can greatly influence the number of people exposed to a coastal flood hazard, and consequently the number of fatalities or societal flood risk (Jonkman et al. 2008). Moreover, several authors have suggested that tourists are more vulnerable than locals in disaster situations, because they are less independent and less familiar with local hazards and the resources that can be relied on to avoid risk (Burby and Wagner 1996; Faulkner 2001). Nonetheless, the effects of tourism have only scarcely been studied in coastal flood risk management. Traditional studies generally use fixed population data in their estimates of casualty numbers, but rarely account for effects of population dynamics such as tourism (Lentz 2006).

Two data issues may be at the basis of this deficiency. Firstly, detailed spatio-temporal data is necessary to map out tourism fluctuations. Coastal tourism is a seasonal phenomenon, with variations according to climate, holiday seasons and seasonal traditions (Ahas et al. 2007). The largest seasonal fluctuations are observed in tourist regions specialised in either winter or summer tourism. However, tourism dynamics may also fluctuate on a daily basis, for example due to the weather conditions, day of the week (weekday vs. weekend) and holidays. Secondly, there is a lack of tools to analyze tourist behaviour regarding storm and flood conditions. Research on tourism dynamics and tourist behaviour in the context of coastal flood risk management is limited to date.

This paper addresses both issues by using detailed tourist census data to analyze tourism dynamics on flood risk assessment in a case study on the Belgian coast. The main research question deals with the potential effects of these tourism dynamics on flood casualty calculations. How can we measure these effects and how should we interpret these? Using a GIS model endorsed by the Flemish government (Deckers et al. 2010), casualty calculations are performed with tourist census data as input. An additional research objective addresses the expected behaviour of tourists in storm surge conditions. Are tourists inclined to continue their holiday plans or are they frightened by the potentially adverse effects of storms? Survey data are applied to answer this question. Outcomes are interpreted in a qualitative way and consequences regarding casualty calculations are discussed.

\section{Background}

\subsection{Societal risk and people at risk}

Within the quantification of risks to people, results are generally expressed by individual risk and/or societal risk. Individual risk refers to the probability that an average, unprotected person is killed at a certain location, whereas the societal risk refers to the probability that a number of people of a given population is killed due to one event (Jonkman et al. 2003). While the former approach is common practice in technical hazards (e.g., the dispersion of toxic gasses, fire, nuclear waste, etc.), the latter is more apposite to natural hazards such as floods and earthquakes. The estimation of the societal risk generally includes three phases (Jonkman 2007): 
1. The assessment of physical effects associated with the hazard, including the dispersion of the effects and the extent of the exposed area;

2. The determination of the number of people in the exposed area;

3. The estimation of the mortality and casualty number amongst the exposed population.

While phase 1 and phase 3 are strongly linked to engineering models, phase 2 is principally a spatiotemporal problem. The main focus in this phase is to find out who is exposed to a hazard, considering population dynamics. In literature, a distinction is often made between the concepts of registered population, people at risk and exposed population (Lentz and Rackwitz 2004). The registered population $N_{P O P}$ are those people that are registered in the municipal. All individuals present in an exposed area are indicated as people at risk, often denoted as $N_{P A R}$. The actually exposed population $N_{E X P}$ refers to all individuals that are exposed to the physical effects of the disaster. In order to estimate the population at risk $\left(N_{P A R}\right)$, Lentz (2006) has identified three approaches: (i) the objectbased approach, (ii) the distribution-based approach and (iii) the conditional distribution-based approach. The distribution-based approach relies on the registered population $N_{P O P}$ of a given area distributed over different buildings and locations as a function of time. This approach is usually applied for large scale events, such as earthquakes or floods (Jonkman et al. 2003). The object-based approach consists of counting all persons entering and leaving a building. Presence fractions can be defined to estimate the number of people in vulnerable buildings or locations (e.g. Mathijsen 2003). The conditional distribution-based approach is a means of applying the distribution-based approach to single objects or groups of similar objects in an effective way without requiring additional data collection (as opposed to the object-based approach). Since the focus of this study is a large scale flood event, the distribution-based approach is employed.

Jonkman et al. (2008) have argued that in large-scale applications with high population numbers, $N_{P A R}$ can safely be approximated by the registered population in the area $N_{P O P}$. In many cases, however, it might be essential to consider population dynamics to avoid crude over- or underestimations of the flood impact. The number of people at risk might, for example, be considerably smaller than the registered population when a part of this population is working outside the exposed area. Conversely, $N_{P A R}$ might be larger when large numbers of tourists visit the area regularly. The effect of time on $N_{P A R}$ is realized at three different levels (Lentz 2006): time of day (i.e. working, sleeping, leisure times), day of the week (working/weekend day) and season.

While fluctuations at the level of daytime have been studied in prior risk assessment studies (e.g. McPherson et al. 2004; Ahola et al. 2007), the effects of tourism fluctuations which primarily occur at the level of day of the week and seasons have garnered less attention. Therefore, the present study will explicitly focus on the effects of seasonal and day-to-day variations in tourist dynamics on coastal flood risk assessment. We will use $N_{R T}$ to denote the time dependent number of residential tourists on the Flemish coast. Assuming $N_{P O P}$ constant over the timescales considered, the population at risk $N_{P A R}$ can then be formulated by:

$$
N_{P A R}(t)=N_{P O P(c)}+N_{R T}(t)
$$

In this study, we will seek to account for this adjusted, time-varying number of people at risk.

\subsection{Coastal tourism, dynamics and tourist behaviour}

Coastal tourism can be defined as the full range of tourism, leisure, and recreationally oriented activities that take place in the coastal zone and the offshore coastal waters, including accommodation, catering industry as well as tourism activities (e.g. swimming, recreational fishing and diving) (Hall 2001). In this study, we use the term coastal tourism specifically for residential tourists in the coastal area, defined as tourists who stay at least two consecutive days on the Belgian coast. Day tourists as well as economic aspects of coastal tourism (e.g. accommodation, catering, etc.) are not considered in the present research. 
Coastal tourism is subject to various dynamics, which are mainly characterized by seasonal variations. Such variations can be attributed to natural and institutional seasonality (Hartman 1986). Natural seasonality refers to regular temporal variations in natural phenomena, particularly those associated with cyclical climatic changes throughout the year, such as temperature, precipitation, wind, and daylight (Butler 1994). Braun et al. (1999) have found that good weather and plenty of sunshine are among the most important expectations regarding vacations. Climate and weather influence the attractiveness of a potential vacation region and require or enable certain kinds of facilities to be offered at the destination. Institutional factors are related to social norms and practices of society and are typically epitomised by holidays (e.g. industrial, school and religious holidays). Within this framework, tourism is seen to be constrained by work and other obligations (Higham and Hinch 2002).

Although tourism seasonality is strongly linked to climate and weather conditions, the relationship between tourist behaviour and weather conditions may be not as straightforward as it may seem. For example, 'bad' weather conditions, such as storms, may not necessarily keep tourists away. Stormy weather above sea can result in spectacular overtopping of water along hard structures, such as rocks or dikes. This occurrence often attracts "storm watchers" or "storm chasers": people who are desired to observe and photograph the power of nature (Cantillon et al. 1999). In this way, inquisitive tourists may become member of the exposed population themselves.

\section{Study area}

\subsection{The Belgian coast: location and characteristics}

The Belgian coast is located along the Southern Bight of the North Sea and measures 65 kilometres. It is characterized by sandy beaches, dune areas and hard defence structures such as groynes and sea walls. Apart from their main function as coastal protection infrastructure, sea walls also play a significant role in recreation (e.g. "promenades" for coast-dwellers, bikers, skaters, etc.) and catering industry (e.g. popular spot for outdoor cafés). Due to the limited length of the coastline and the increasing population pressure, most of the coastal zone has become urbanized and half of the coastal dunes has disappeared (Charlier and Demeyer 1995). Figure 1 depicts the location of the ten coastal municipalities included in this study. Approximately 0.2 million people $(2 \%$ of the Belgian population) live in this area. The mean population density amounts to more than 500 inhabitants per $\mathrm{km}^{2}$, but in several statistical sectors ${ }^{1}$, population density runs up to thousands of people per $\mathrm{km}^{2}$. The city of Oostende is with ca. 65000 inhabitants the largest population centre on the Belgian coast, followed by Knokke-Heist (ca. 32000 inhabitants) and Koksijde (ca. 20000 inhabitants). The entire coastal area is attractive to many human activities, such as recreation, fishery, shipping, agriculture, trade, etc. Particularly the recreational attractiveness causes an increase in population with approximately 0.3 million residential tourists during summer (Lebbe et al. 2008).

The high degree of urbanization and tourism activities makes the Belgian coast extremely vulnerable to coastal flooding. It is therefore an intriguing area to study the relation between tourism dynamics and coastal flood risks.

\footnotetext{
${ }^{1}$ Statistical sectors are arbitrary areas used to aggregate socio-economic statistics. The origin of these sectors lies in the early 70s, when the National Institute of Statistics (NIS, Belgium) was looking for a small territorial entity as a basis for socio-economic data. Sectors were chosen with equal morphologic and social characteristics. In this way, densely populated areas were split up in many small sectors, while sectors in rural less populated - areas generally larger.
} 


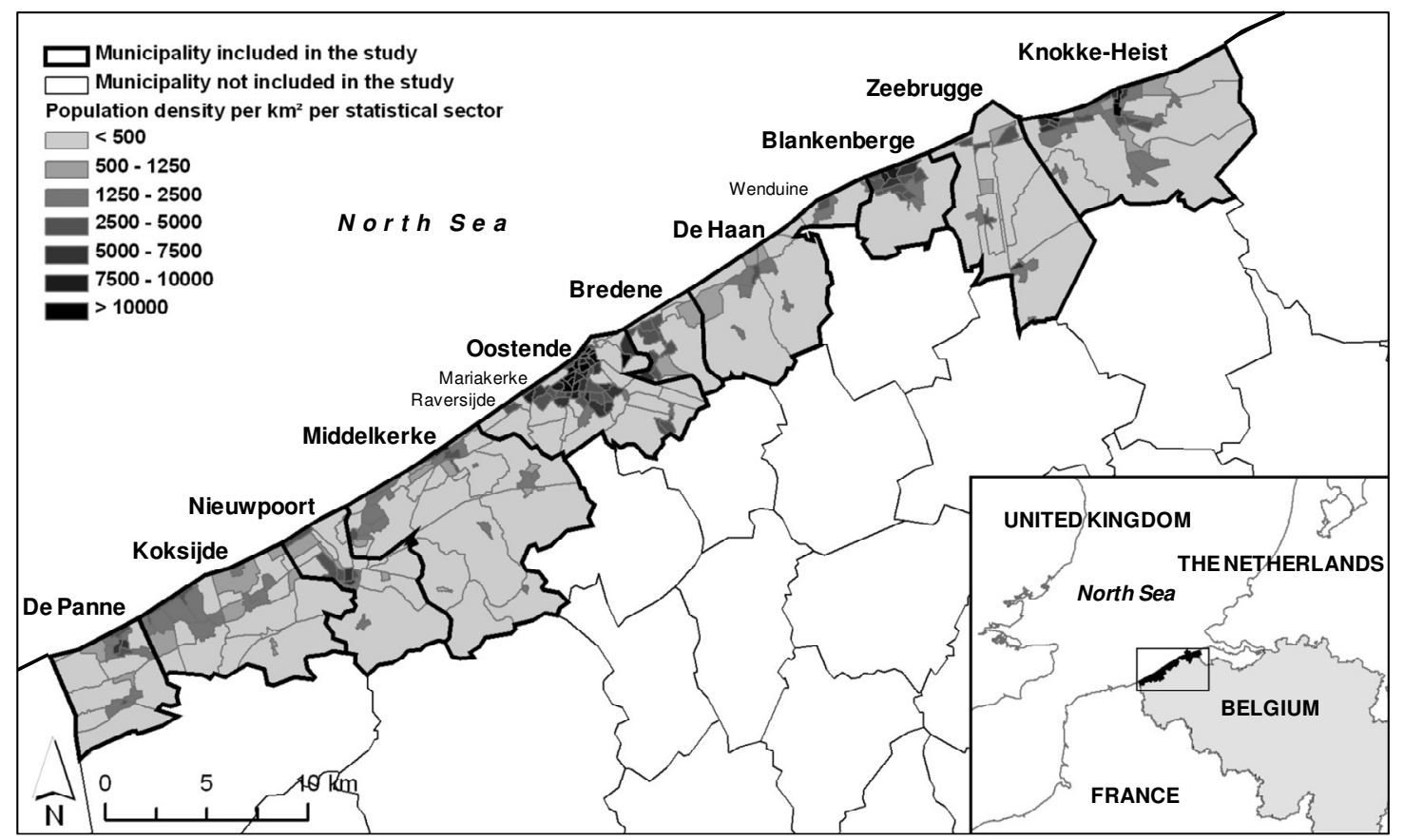

Figure 1 Location of study area

\subsection{Flood risks on the Belgian coast}

In the past, several storm surges have affected the Belgian coast. During the severe storm flood disaster of 1953, eight people died in the city of Oostende. Since the record water level in 1953 $\left(666 \mathrm{~cm} \mathrm{TAW}^{2}\right)$, high water levels were measured in $1976(590 \mathrm{~cm}$ TAW), 1993 (596 cm TAW) and 1997 (593 cm TAW). In the years ensuing the flood disaster of 1953, an important part of the Flemish sea walls was reinforced (Charlier and Demeyer 1995). According to the outcomes of the Master Plan for Coastal Safety (Mertens et al. 2010), today about one third of the Belgian coast can be considered vulnerable to a coastal flood. Most vulnerable are the city centre of Oostende and the coastal villages of Raversijde, Mariakerke and Wenduine (cf. Figure 1 for their location). The Master Plan seeks solutions to cope with future coastal floods, considering climate change impacts until 2050. The project aims at protecting the coast against floods with a recurrence period of 1000 years. Among the measures that are explored, beach nourishment and dike enforcements (e.g. building storm walls) are considered the most effective defence structures for the Belgian coast.

While coastal floods can be caused by various factors, such as windstorms, seismic activity (tsunami) and tidal waves (Jonkman 2005), coastal flood risk management in Belgium is primarily focused on one plausible causer: windstorms. Northwesterly storms are particularly hazardous for the Belgian coast, since they push up the North Sea water toward the coastal areas. The situation becomes disastrous if these storms coincide with spring tide, which was the case in 1953 (McRobie et al. 2005). In the low-land areas, windstorms occur mostly from October to April. However, even in the summer half of the year, storms remain possible. Exploratory POT-analyses (peak over threshold) on the Belgian coast revealed that the probability of an extreme storm is about five times larger during winter than during summer (analyses performed in the context of the Master Plan for Coastal Safety).

\footnotetext{
${ }^{2}$ TAW is a Dutch abbreviation for "Tweede Algemene Waterpassing". An altitude of $0 \mathrm{~m}$ TAW corresponds to the average low spring tide level at Oostende.
} 


\section{Data and methodology}

\subsection{Research approach}

Figure 2 schematically represents the research approach that is employed in this study. First of all, the number of residential tourists on the Belgian coast $\left(N_{R T}\right)$ is estimated through tourism dynamics, which are based on the occupancy of second residences. Tourist behaviour, measured through a field survey, is also linked to the tourist number, yet in a qualitative way (cf. Section 5.3). The addition of the registered population $\left(N_{P O P}\right)$ and the number of residential tourists gives the total number of people at risk $\left(N_{P A R}\right)$. Furthermore, two models are employed in this study: a flood model and a GIS model. The flood model determines a set of flood characteristics (water depth, rise velocity and flow velocity) from a set of storm characteristics or assumptions (storm surge level, wave height). The flood model is based on the worst case scenario of the BELSPO project CLIMAR. The GIS model ascertains the number of human casualties from these flood characteristics and the number of people at risk through mortality functions.

The next paragraphs of this section provide more information about the data sets and models which are grey-coloured in Figure 2.

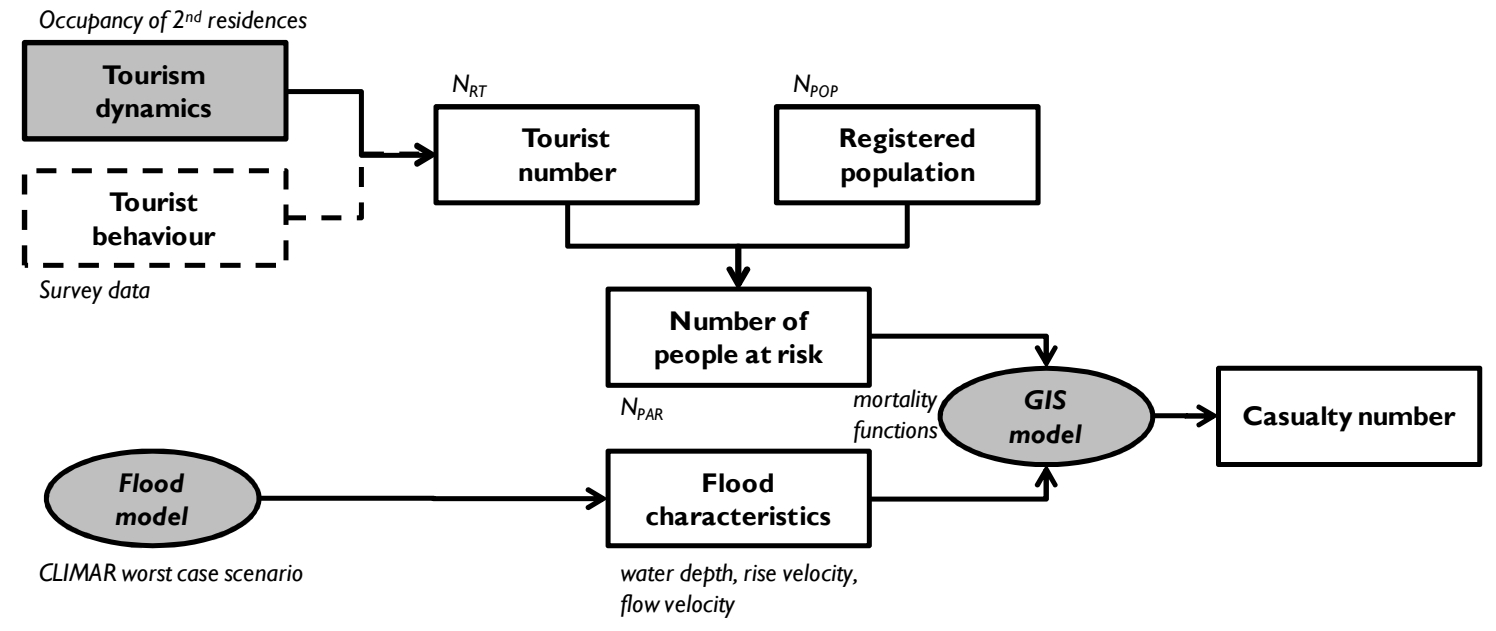

Figure 2 Flowchart of the research approach

\subsection{Location and occupancy of second residences}

Within the framework of the Belgian coastal Action Plan (2005-2009), the West Flanders Economic Agency (WES) has held a large-scale survey with regard to the use and occupancy of second residences on the Belgian coast. About 5100 inland and foreign home-owners were queried, representative towards country, region, municipality and time of the year. The WES survey filled up an important gap in coastal tourist data in Flanders since only a relatively small part of all nights on the Belgian coast is registered on a regular basis, leading to an underestimation of the tourist significance of the coastal area. In their study, WES defined second residences as private dwellings with recreational purposes which are included in the direct taxes. The owners of these second residences are not registered in the municipal and pay second residence taxes. For instance, apartments, villas, bungalows and studio flats, which are not used for professional purpose, and do not have a first domicile on their address, are included in this study. Second residences represent about three-quarter of both the accommodation capacity and the total number of nights on the Belgian coast. The remaining quarter, which comprises accommodation in "open air" (such as camp sites, holiday domains, etc.), hotels and other (e.g. accommodation for specific audience such as the elderly) is not considered in the WES survey. A second residence on the Belgian coast is occupied for 100 nights a 
year on average. The home-owner stays on average about 54 nights in his residence, lets about 15 nights to friends and family for free and lets about 31 nights to third parties (Gunst et al. 2008).

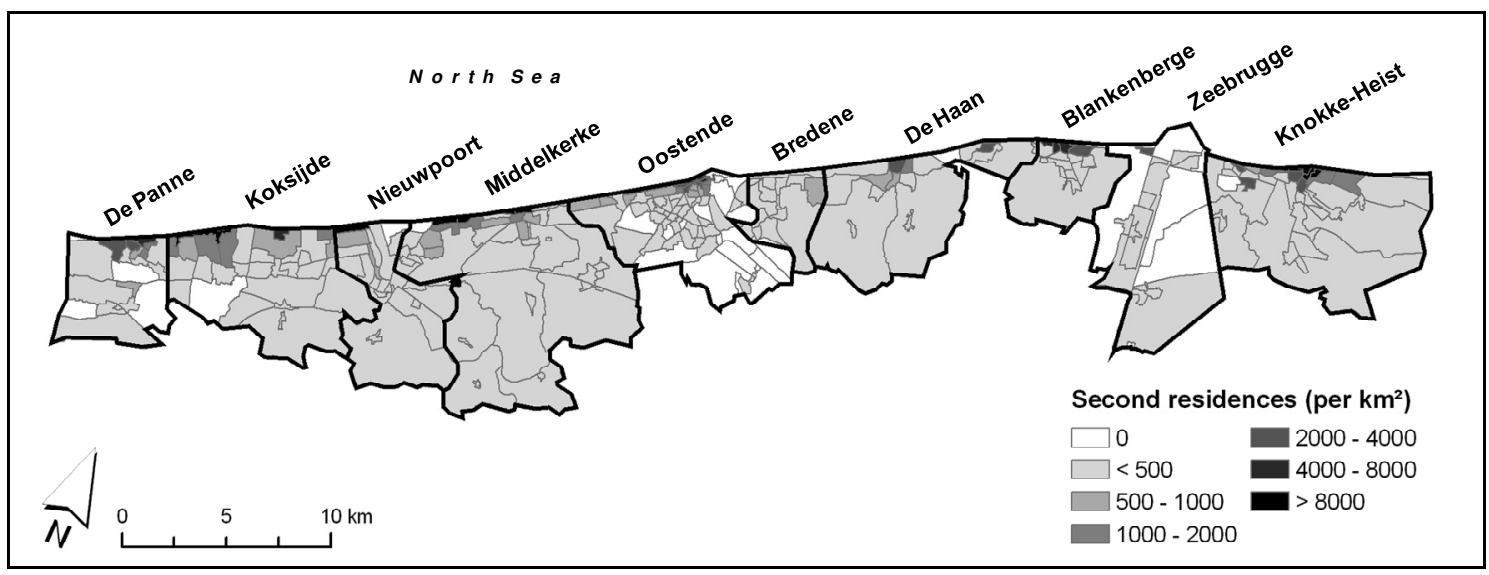

Figure 3 Number of second residences on the Belgian coast (per $\mathrm{km}^{2}$ )

The number of second residences on the Belgian coast is higher than in any other Flemish municipality. In 2007, 82700 second residences were registered in ten coastal municipalities. Table 1 lists the number of second residences in each municipality. Previous counts of second residences (including holiday parks) show an increase of 23\% between 1989 and 1997 and an increase of $16 \%$ between 1997 and 2007. This corresponds with a mean annual increase of about $2.4 \%$ or 1400 second residences over the period 1989-2007 (Gunst et al. 2008). Figure 3 depicts the density of second residences per $\mathrm{km}^{2}$ for each statistical sector. The highest concentrations of second residences are found in the statistical sectors bordering the coastline. About $70 \%$ of the second residences is located at a distance of less than $300 \mathrm{~m}$ from the coast.

Table 1 Number of second residences and portion per municipality (Gunst et al. 2008)

\begin{tabular}{llllll}
\hline Municipality & $\begin{array}{l}\text { Number of } \\
\text { second } \\
\text { residences }\end{array}$ & $\%$ & Municipality & $\begin{array}{l}\text { Number of } \\
\text { second } \\
\text { residences }\end{array}$ & $\begin{array}{l}\text { \% } \\
\text { De Panne }\end{array}$ \\
Koksijde & 1357 & $7.7 \%$ & Bredene & 1205 & $1.5 \%$ \\
Nieuwpoort & 8315 & $16.8 \%$ & De Haan & 6732 & $8.1 \%$ \\
Middelkerke & 14272 & $10.1 \%$ & Blankenberge & 6747 & $0.8 \%$ \\
Oostende & 6717 & $17.3 \%$ & Zeebrugge & 677 & $21.5 \%$ \\
\hline Total 2007 & 82700 & $8.1 \%$ & Knokke-Heist & 17772 & \\
Total 2007* & 83405 & & & & \\
Total 1997* & 71685 & & & & \\
Total 1989* & 58262 & & & & \\
\hline *including residences in holiday parks & & & & \\
\end{tabular}

From the WES survey, three raw data sets are used in this study: (i) the number of second residences per statistical sector, (ii) the daily occupancy of second residences (June 2007 - May 2008) for the entire coast and (iii) the average number of persons per second residence (per municipality). From these data sets, the number of residential tourists $N_{R T}$ is estimated per statistical sector for a given timescale (cf. Section 5.1).

Combining the number of second residences per statistical sector with the average number of persons per second residence, an estimated maximum of residential tourists $\left(N_{R T(M A X)}\right)$ can be defined. Figure 4 depicts the ratio of $N_{R T(M A X)}$ to the number of people at risk $\left(N_{P A R}\right)$ per statistical sector. The map highlights those sectors where high percentages of tourists reside relative to the number of registered people. A significant part of the sectors adjacent to the coastline is touristy, but several sectors in the 
hinterland show high ratios as well. In section 5.2, we will examine how these findings turn out with respect to flooding.

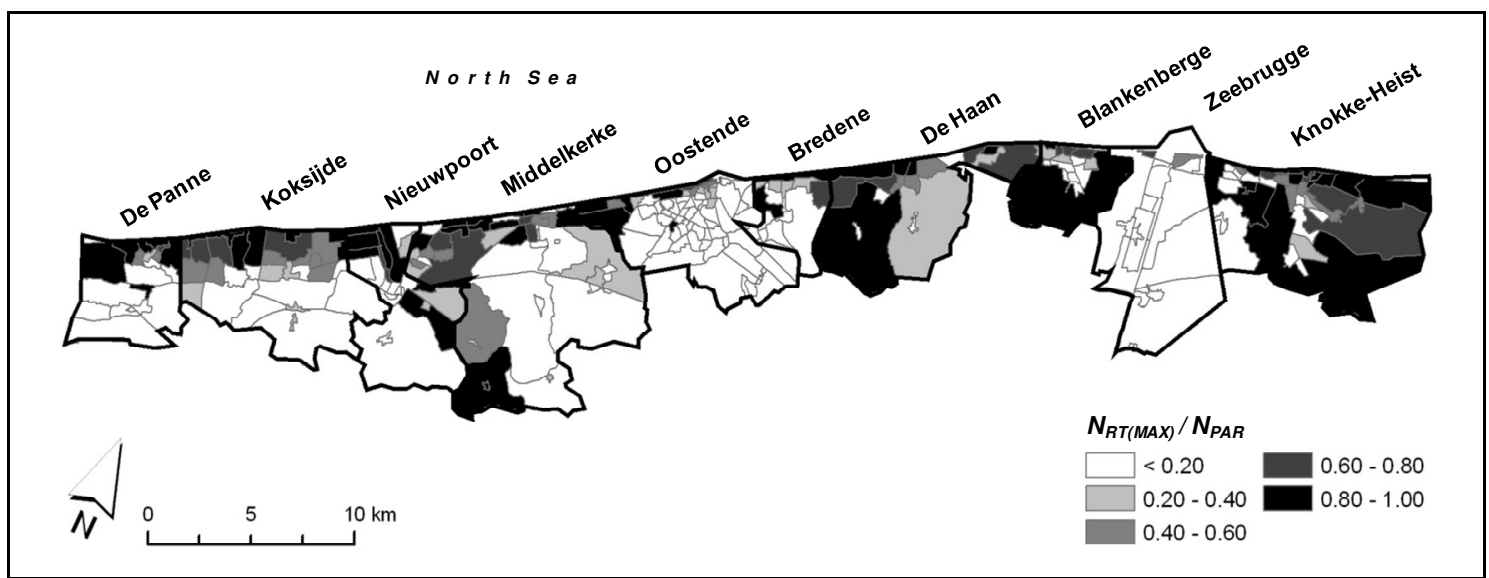

Figure 4 Ratio between the number of residential tourists (assuming all second residences are occupied, $N_{R T(M A X)}$ ) and the number of people at risk $\left(N_{P A R}\right)$

\subsection{Flood model}

This study uses the results of a flood model that is currently in use in the framework of the Belgian BELSPO project CLIMAR (Van der Biest et al. 2008). CLIMAR proposes adaptation techniques specific to the Belgian coast with regard to climate change and sea level rise. Two time horizons are studied in this context: 2040 and 2100. For both time horizons, WCS (worst case scenario) flood models have been implemented for corresponding changes in hydrodynamic boundary conditions (Ponsar et al. 2007). Since uncertainty levels are increasing enormously with prediction horizons, the model closest to the present is chosen. WCS 2040 is based on a maximum storm surge level of $8.71 \mathrm{~m}$ TAW and a significant wave height of $8.77 \mathrm{~m}$ (Reyns et al. 2010). According to the model, this "super storm" will cause dozens of dike breaches along the Belgian coast. Figure 5 shows the flood extents and water depths which are to be expected in the coastal region. The floods are mainly situated in two regions: Middelkerke/Oostende and Blankenberge/De Haan (Wenduine). Particularly in the low-lying city centre of Oostende, record water depths are estimated of ca. $4.9 \mathrm{~m}$. Elsewhere, water depths vary between $0.2 \mathrm{~m}$ and $1.5 \mathrm{~m}$. The lines in the flood areas represent roads. The rectangular dark area south of Blankenberge is a very low-lying polder, originated from peat exploitation. Given the current climate change models, the estimated return period of this extreme flood scenario is about 7000 years by 2040 .

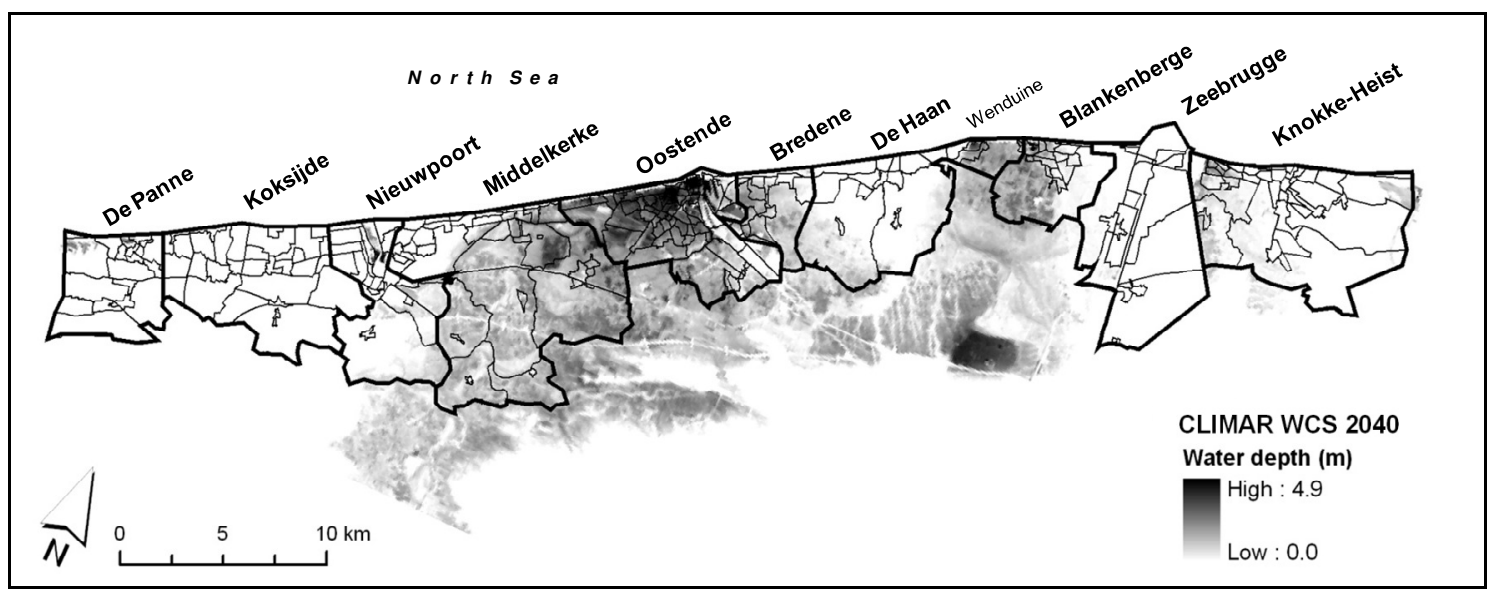

Figure 5 Flood extents and water depths according to the CLIMAR WCS 2040 flood model 


\subsection{GIS model}

Since 2007, the Flemish government is using a GIS tool for the support of its flood risk management, called LATIS. The tool is developed by Ghent University and Flanders Hydraulics Research and functions as a shell around the raster based IDRISI software (Clark Labs). Based on the Flemish flood risk methodology (see Vanneuville et al. 2006 for a comprehensive discussion), LATIS allows the user to perform risk computations for both economic losses and casualties. Critical mortality parameters in the present methodology are water depth, rise velocity and flow velocity. The number of casualties is determined as a percentage of the number of inhabitants $\left(N_{P O P}\right)$. It grows exponentially with water depth and linearly with rise velocity and flow velocity (Deckers et al. 2010).

In the present study, LATIS is used to calculate the casualties among the registered population (denoted as $\left.C_{P O P}\right)$ and the casualties among the residential tourists $\left(C_{R T}\right)$. The total number of casualties $C_{T O T}$ is defined as the sum of $C_{P O P}$ and $C_{R T}$.

\section{Results}

\subsection{Seasonal tourism on the Belgian coast}

The WES survey data comprises estimated daily tourist numbers at the Belgian coast between June 2007 and May 2008. The 366 observations recorded within this period are aggregated into a number of categories, allowing us to work with meaningful scenarios. Eight separated scenarios are defined as follows: weekdays, weekend days, no holidays, holidays, spring days, summer days, autumn days and winter days. Based on these separated scenarios, 16 combinations are possible. It should be noted that the seasons are defined according to the generally accepted dates in the northern hemisphere: spring starts on March $21^{\text {st }}$, summer on June $21^{\text {st }}$, autumn on September $21^{\text {st }}$ and winter on December $21^{\text {th }}$. Holidays comprise all official holidays (both religious and social) as well as school holidays for children younger than 18 years. These school holidays encompass 14 weeks a year: 8 weeks in summer (July and August), one week around All Saints' (November), two weeks around Christmas (December/January), one week around carnival (February) and two weeks around Easter (March/April).

Figure 6 depicts the mean occupancy of second residences with the corresponding number of residential tourists $N_{R T}$ for each of the 16 time scenarios. Summer is obviously the most attractive season of the Belgian coast. It does not matter if it is weekday or weekend, holiday or not, the mean occupancy is always higher compared to the respective scenarios in spring, autumn or winter. On average, there are more second residences occupied during weekends than on weekdays, regardless of whether or not weekdays fall within a holiday period. As expected, the difference between the occupancy on weekdays and weekends is smaller during holidays than outside holidays. Furthermore, the mean occupancy of second residences is more or less similar in autumn and winter.

With regard to the mean tourist number, we notice that weekend days and holidays attract on average about 250000 to 280000 tourists during summer. This corresponds to a mean occupancy of $61 \%$ to $70 \%$. In spring, the maximum number of tourists is on average about 200000 . Except for summer, the mean tourist number does not exceed 100000 during regular weekdays (no holidays) and does not exceed 200000 during regular weekends (no holidays). One may notice that the mean occupancy during the winter is slightly higher than during the autumn. This is presumably because there are more holidays in winter relative to autumn. Moreover, the weather conditions in Belgium are traditionally better in winter (cold but stable) than in autumn (windy and rainy). The overall mean occupancy of the second residences on the Belgian coast is estimated at $32.5 \%$, which corresponds to a daily mean tourist number of 130000 people residing in the coastal area. 


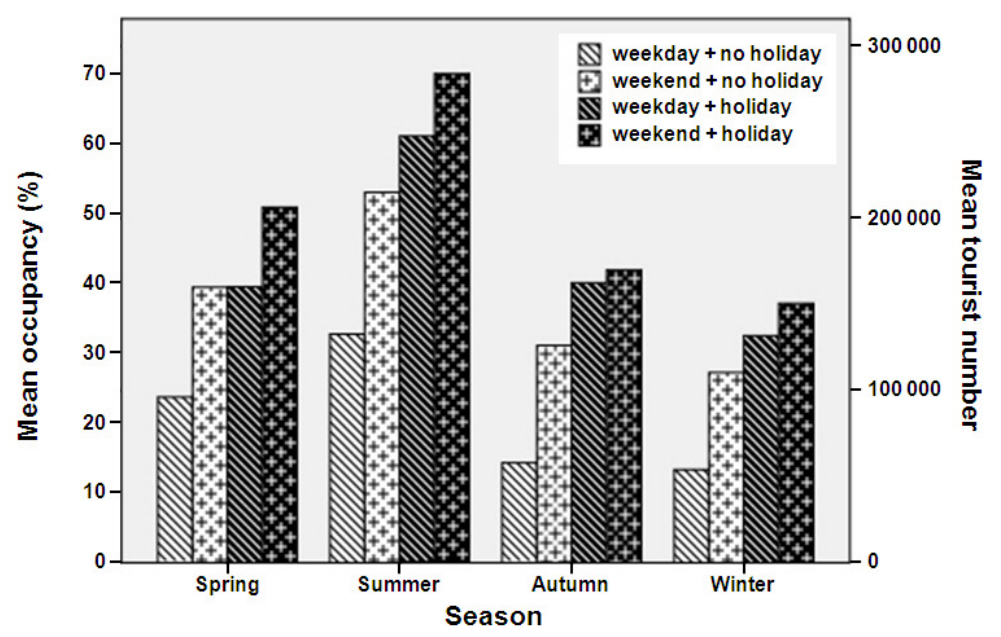

Figure 6 Mean occupancy of second residences and mean tourist number on the Belgian coast for various scenarios

Employing a Scheffé post-hoc test, significant differences were found between the mean tourist number in spring and summer $(p<.001)$, but not between autumn and winter $(p=1)$. Regardless of the season, the mean tourist number on weekdays or weekends differs significantly $(t=-7.32, \mathrm{df}=$ $364, p<.001$, two-tailed), as well as on holidays or non-holidays $(t=-18,86, \mathrm{df}=184.28, p<.001$, two-tailed). An unplanned comparison on the combined scenarios revealed significant differences in mean tourist number between the combination "weekday + no holiday" and "weekend + holiday" ( $p<$ $0.001)$. However, no significant differences were observed between "weekday + holiday" and "weekend + holiday" $(p=.11)$.

Summarized, coastal tourism fluctuations differ significantly between the summer half year and the winter half year, as well as on the level of day of week. Holidays play an unmistakably important role in occupancy of second residences. With these outcomes, we have found evidence for the significance of the factor time within $N_{R T}$ (cf. Section 2.1).

\subsection{Casualty calculations}

The results of the LATIS computations are presented geographically in two figures. Figure 7 depicts the number of casualties per $\mathrm{m}^{2}$ among the registered population $\left(C_{P O P}\right)$, Figure 8 represents the number of casualties per $\mathrm{m}^{2}$ among the residential tourists on the assumption that all second residences are occupied $\left(C_{R T(M A X)}\right)$. 


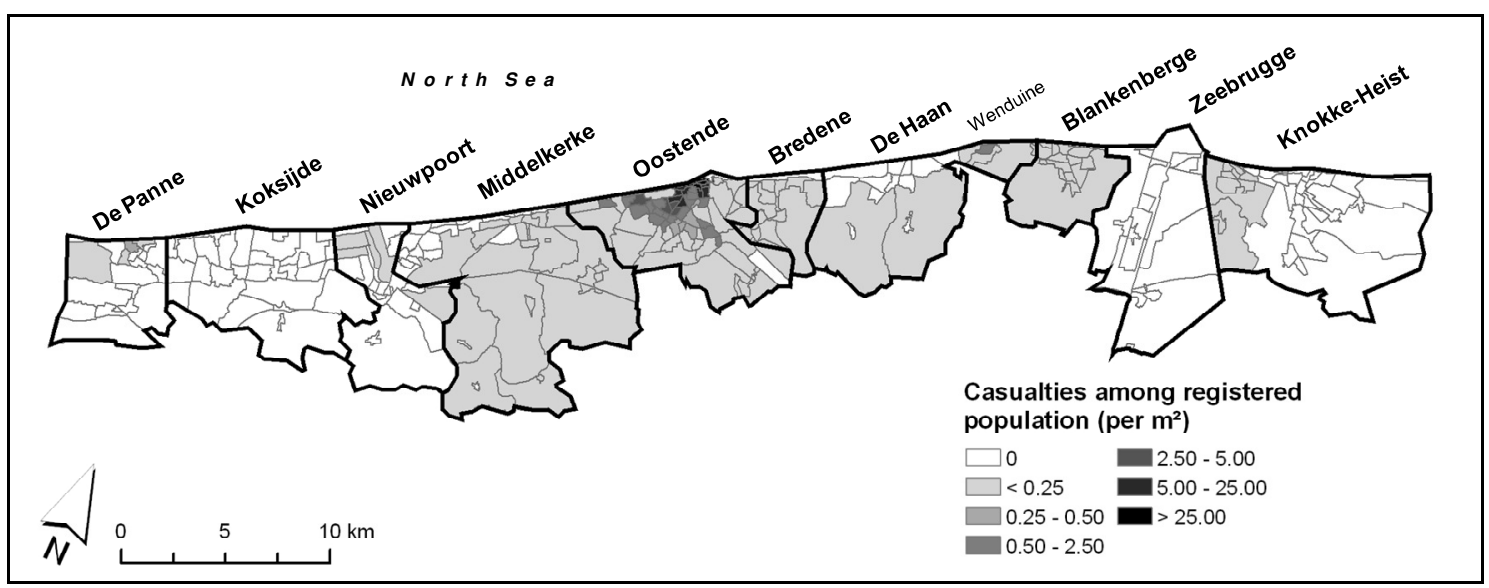

Figure 7 Casualties among registered population ( $C_{P O P}$, flood model: CLIMAR WCS 2040)

As for $C_{P O P}$ (Figure 7), it is clear that impact of the CLIMAR flood model is marked in the city of Oostende. Close to the coastline, several sectors indicate estimations of more than 25 casualties per $\mathrm{km}^{2}$ among the registered population. Other noticeable impacts are observed in Wenduine, a small town near Blankenberge.

A slightly different image is obtained for the computations of $C_{R T(M A X)}$ (Figure 8). Compared to $C_{P O P}$, $C_{R T}$ is more pronounced in those sectors bordering the coastline. Marked impacts of the CLIMAR flood model are particularly observed in Oostende, Wenduine and De Panne. In Oostende, several sectors adjacent to the coastline indicate densities of more than 25 casualties per $\mathrm{km}^{2}$. The centres of De Panne and Wenduine, both very close to the coastline, represent areas with densities over one and six casualties per $\mathrm{km}^{2}$ respectively.

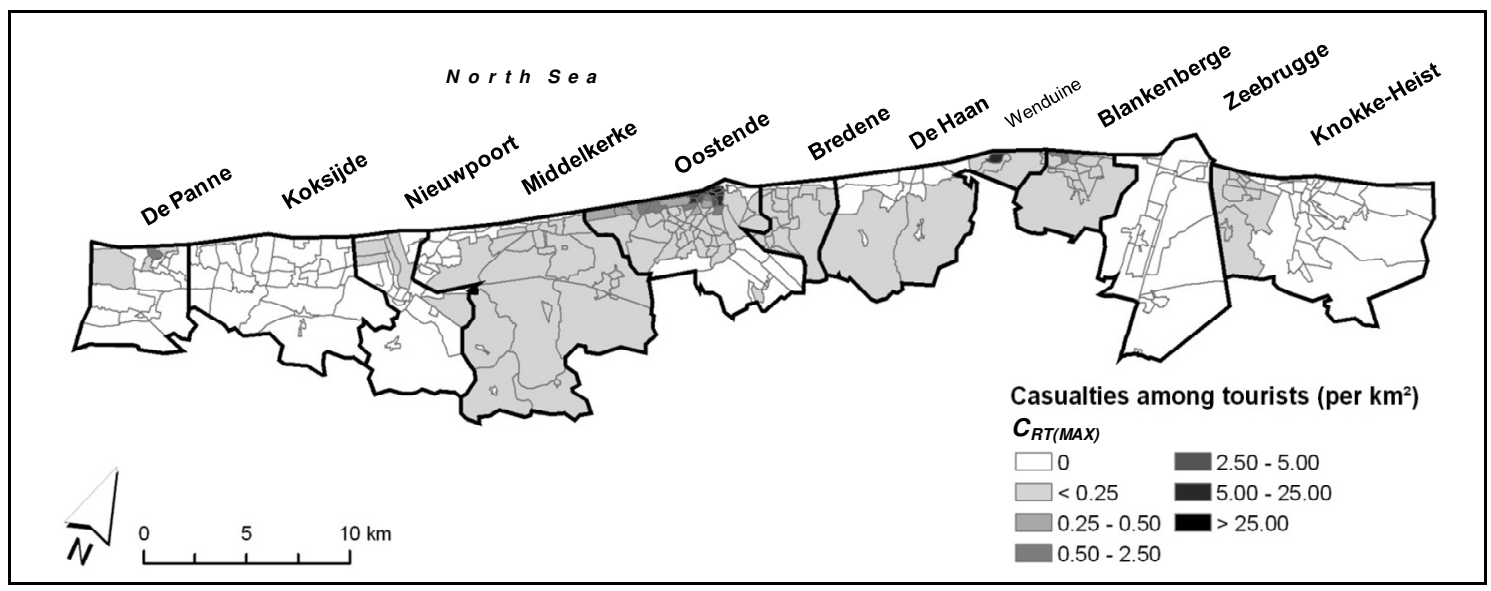

Figure 8 Casualties among tourists $\left(C_{R T(M A X)}\right.$, flood model: CLIMAR WCS 2040)

Table 2 presents for each municipality the absolute numbers of the registered population $\left(N_{P O P}\right)$, the casualties among the registered population $\left(C_{P O P}\right)$, the maximum number of residential tourists $\left(N_{R T(M A X)}\right)$ and the casualties among these tourists $\left(C_{R T(M A X)}\right)$. Further, absolute numbers are presented for a summer and winter scenario. For both scenarios, the mean occupancy of the second residences was used (56.1\% for summer; $21.4 \%$ for winter). We recall that the number of people at risk $N_{P A R}$ equals the sum of $N_{P O P}$ and $N_{R T}$ and that the total number of casualties $C_{T O T}$ for both scenarios is defined as the sum of $C_{P O P}$ and $C_{R T}$. 
On summer days there are over 0.4 million people at risk in the ten coastal municipalities. More than half of them are residential tourists. In winter, tourists weigh less heavily on the total number. Then there are on average nearly 0.3 million people at risk, of whom $30 \%$ are residential tourists. The percentages in the $N_{R T}$ column of Table 2 represent the portion of residential tourists $\left(N_{R T}\right)$ against the total number of people at risk. Regarding tourism, the most vulnerable municipalities are Middelkerke $\left(N_{R T} / N_{P A R}=71.5 \%\right)$, Koksijde $\left(N_{R T} / N_{P A R}=67.8 \%\right)$ and Nieuwpoort $\left(N_{R T} / N_{P A R}=67.3 \%\right)$. Least vulnerable are Bredene $\left(N_{R T} / N_{P A R}=19.9 \%\right)$ and Zeebrugge $\left(N_{R T} / N_{P A R}=15.7 \%\right)$. Figure 4 shows the spatial variations for a geographical output of the $N_{R T} / N_{P A R}$ ratio at the level of the statistical sector.

For three municipalities - Nieuwpoort, Zeebrugge and Koksijde - few or no casualties are estimated. The WCS 2040 flood extents are negligible in these municipalities (cf. Figure 5). We ignore them in the remainder. The vast majority of casualties falls in Oostende (ca. 98\%), followed by De Haan, Blankenberge and De Panne. The percentages in the $C_{R T}$ column of Table 2 represent the impact of casualties among the residential tourists $\left(C_{R T}\right)$ compared to the total number of victims for that scenario $\left(C_{T O T}\right)$. We observe that the impact of $C_{R T}$ is highest in the municipalities Blankenberge, De Haan and De Panne. In the summer scenario, $60.6 \%$ to $74.1 \%$ of the casualties are residential tourists. This percentage is lower in the winter scenario, but still more than $50 \%$ for De Haan and De Panne. The marked outcomes for De Haan are mainly due to the losses in Wenduine. In the municipalities Bredene, Knokke-Heist and Middelkerke, the impact of residential tourism on the total number of casualties is rather limited. The percentage of $C_{R T}$ in the city of Oostende amounts to $36.3 \%$ in summer and $17.9 \%$ in the winter. These values are lower than in Blankenberge, De Haan and De Panne, but they represent hundreds of casualties.

In conclusion, marked outcomes are particularly observed in flooded sectors having a high $N_{R T} / N_{P A R}$ ratio. This is mostly the case in those sectors adjacent to the coastline, which are also most vulnerable to flooding. The casualty calculations indicate that considering tourism dynamics can produce a significant impact, which can also vary significantly in time. 
Table 2 Summary of casualty computations for each municipality

\begin{tabular}{|c|c|c|c|c|c|c|c|c|c|c|c|c|}
\hline \multirow[b]{2}{*}{ Municipality } & \multirow[b]{2}{*}{$\mathbf{N}_{\text {POP }}$} & \multirow[b]{2}{*}{$\mathrm{C}_{\text {POP }}$} & \multirow[b]{2}{*}{$\mathbf{N}_{\mathbf{R T}(\text { MAX) }}$} & \multirow[b]{2}{*}{$\mathrm{C}_{\mathrm{RT}(\mathrm{MAX})}$} & \multicolumn{4}{|c|}{ Summer } & \multicolumn{4}{|c|}{ Winter } \\
\hline & & & & & $\mathbf{N}_{\mathrm{RT}}$ & $\mathbf{N}_{\text {PAR }}$ & $\mathbf{C}_{\mathrm{RT}}$ & $\mathbf{C}_{\text {TOT }}$ & $\mathbf{N}_{\mathbf{R T}}$ & $\mathbf{N}_{\text {PAR }}$ & $\mathbf{C}_{\mathrm{RT}}$ & $\mathbf{C}_{\text {TOT }}$ \\
\hline Blankenberge & 17386 & 4.83 & 29322 & 13.23 & $\begin{array}{l}16450 \\
48.6 \%\end{array}$ & 33836 & $\begin{array}{c}7.42 \\
60.6 \%\end{array}$ & 12.26 & $\begin{array}{c}6275 \\
26.5 \%\end{array}$ & 23661 & $\begin{array}{c}2.83 \\
36.9 \%\end{array}$ & 7.66 \\
\hline Bredene & 12633 & 3.90 & 5602 & 0.25 & $\begin{array}{c}3143 \\
19.9 \%\end{array}$ & 15776 & $\begin{array}{l}0.14 \\
3.4 \%\end{array}$ & 4.04 & $\begin{array}{l}1199 \\
8.7 \%\end{array}$ & 13832 & $\begin{array}{l}0.05 \\
1.3 \%\end{array}$ & 3.95 \\
\hline De Haan & 11126 & 11.35 & 35058 & 57.85 & $\begin{array}{l}19668 \\
63.9 \%\end{array}$ & 30794 & $\begin{array}{l}32.46 \\
74.1 \%\end{array}$ & 43.81 & $\begin{array}{c}7502 \\
40.3 \%\end{array}$ & 18628 & $\begin{array}{c}12.38 \\
52.2 \%\end{array}$ & 23.73 \\
\hline De Panne & 9870 & 2.42 & 31149 & 14.50 & $\begin{array}{l}17475 \\
63.9 \%\end{array}$ & 27345 & $\begin{array}{c}8.13 \\
77.1 \%\end{array}$ & 10.55 & $\begin{array}{c}6666 \\
40.3 \%\end{array}$ & 16536 & $\begin{array}{c}3.10 \\
56.2 \%\end{array}$ & 5.52 \\
\hline Knokke-Heist & 32394 & 3.57 & 92414 & 1.59 & $\begin{array}{l}51844 \\
61.5 \%\end{array}$ & 84238 & $\begin{array}{c}0.89 \\
20.0 \%\end{array}$ & 4.47 & $\begin{array}{l}19777 \\
37.9 \%\end{array}$ & 52171 & $\begin{array}{l}0.34 \\
8.7 \%\end{array}$ & 3.91 \\
\hline Koksijde & 20052 & 0.00 & 75419 & 0.00 & $\begin{array}{l}42310 \\
67.8 \%\end{array}$ & 62362 & $\begin{array}{c}0.00 \\
--\end{array}$ & 0.00 & $\begin{array}{l}16140 \\
44.6 \%\end{array}$ & 36192 & $\begin{array}{c}0.00 \\
--\end{array}$ & 0.00 \\
\hline Middelkerke & 16503 & 3.04 & 73775 & 1.89 & $\begin{array}{l}41388 \\
71.5 \%\end{array}$ & 57891 & $\begin{array}{c}1.06 \\
25.9 \%\end{array}$ & 4.10 & $\begin{array}{l}15788 \\
48.9 \%\end{array}$ & 32291 & $\begin{array}{c}0.40 \\
11.7 \%\end{array}$ & 3.44 \\
\hline Nieuwpoort & 10244 & 0.01 & 37562 & 0.06 & $\begin{array}{l}21073 \\
67.3 \%\end{array}$ & 31317 & $\begin{array}{c}0.03 \\
85.9 \%\end{array}$ & 0.04 & $\begin{array}{c}8038 \\
44.0 \%\end{array}$ & 18282 & $\begin{array}{c}0.01 \\
70.0 \%\end{array}$ & 0.02 \\
\hline Oostende & 65688 & 1906.04 & 28887 & 1939.45 & $\begin{array}{l}16206 \\
19.8 \%\end{array}$ & 81894 & $\begin{array}{c}1088.03 \\
36.3 \%\end{array}$ & 2994.07 & $\begin{array}{l}6182 \\
8.6 \%\end{array}$ & 71870 & $\begin{array}{l}415.04 \\
17.9 \%\end{array}$ & 2321.08 \\
\hline Zeebrugge & 9168 & 0.00 & 3047 & 0.00 & $\begin{array}{c}1709 \\
15.7 \%\end{array}$ & 10877 & $\begin{array}{c}0.00 \\
--\end{array}$ & 0.00 & $\begin{array}{c}652 \\
6.6 \%\end{array}$ & 9820 & $\begin{array}{c}0.00 \\
--\end{array}$ & 0.00 \\
\hline Total & 205064 & 1935.16 & 412237 & 2028.82 & $\begin{array}{c}231265 \\
53.0 \% \\
\end{array}$ & 436329 & $\begin{array}{c}138.17 \\
37.0 \% \\
\end{array}$ & 3073.33 & $\begin{array}{l}88219 \\
30.1 \% \\
\end{array}$ & 293283 & $\begin{array}{r}434.17 \\
18.3 \% \\
\end{array}$ & 2369.33 \\
\hline
\end{tabular}

$\mathrm{N}_{\mathrm{POP}}=$ registered population; $\mathrm{C}_{\mathrm{POP}}=$ estimated casualties among registered population; $\mathrm{N}_{\mathrm{RT}(\mathrm{MAX})}=$ estimated maximum of residential tourists; $\mathrm{C}_{\mathrm{RT}(\mathrm{MAX})}=$ maximum number of casualties among the residential tourists (all second residences occupied); $\mathrm{N}_{\mathrm{RT}}=$ number of residential tourists; $\mathrm{N}_{\mathrm{PAR}}=$ number of people at risk; $\mathrm{C}_{\mathrm{RT}}=$ estimated number of casualties among the residential tourists; $\mathrm{C}_{\mathrm{TOT}}=$ total estimated number of casualties. 


\subsection{Tourist behaviour in stormy weather}

Survey data is used to gain qualitative insights in the behaviour of tourists in stormy weather conditions on the Belgian coast. In a quasi-experimental design, residential tourists were asked to imagine two storm scenarios (A and B, cf. Table 3 for a verbal transcription of both scenarios) and express their degree of agreement on three items ( 1 item related to storm scenario A, 2 items related to storm scenario B, cf. Table 4).

Table 3 Verbal transcription of the two storm scenarios

\begin{tabular}{ll}
\hline Scenario A & Assume you have booked a holiday week on the Belgian coast. On the day of your depart, \\
& radio and television are paying much attention to a heavy storm which will approach the \\
& Belgian coast in the next days. The Royal Meteorological Institute (KMI) predicts wind \\
speeds over $75 \mathrm{~km} / \mathrm{h}(>9$ Beaufort) and warns for large waves along the coast and \\
dangerous situations on the dike promenades as a result of overtopping water. \\
A storm similar to the one in scenario A approaches the coast. Assume you are staying on \\
the coast for holidays at the time you hear about this storm and the warnings.
\end{tabular}

Table 4 Items for storm scenarios $A$ and $B$

\begin{tabular}{|c|c|c|}
\hline $\begin{array}{l}\text { Storm } \\
\text { scenario }\end{array}$ & $\begin{array}{l}\text { Item } \\
\text { number }\end{array}$ & Item \\
\hline A & 1 & I cancel my trip to the sea immediately. \\
\hline B & 1 & I leave the coastal area immediately and go back home. \\
\hline B & 2 & $\begin{array}{l}\text { Stormy weather can cause spectacular pictures. I stay on the coast to watch the } \\
\text { storm. }\end{array}$ \\
\hline
\end{tabular}

The questions on tourist behaviour were part of a larger survey which probed the public's perceptions regarding coastal flood risks and coastal defence structures (see Kellens et al. 2011). The overall response rate was approximately $20 \%$. The sample that is used here consists of 175 residential tourists, of which $32 \%$ are women $(N=56)$ and $68 \%$ are men $(N=119)$. The sample's age ranges from 17 to 83 years $(M=56.8, S D=13.8)$.

Table 5 presents the results of the questionnaire. As for scenario A, where the respondent is supposed to set off for a trip to the sea when weather forecasts predict major storms, we found that only $22 \%$ will cancel their trip immediately (A1). In scenario B, where the respondent is supposed to stay at the coast at the moment the storm is forecasted, about one third of the respondents will leave the coastal area immediately (B1). Noticeably, almost half of the respondents answers that they would stay on the coast, just to watch the storm (B2).

Table 5 Questionnaire results on tourist behaviour in stormy weather

\begin{tabular}{lllllll}
\hline & \multicolumn{2}{c}{ No agreement } & \multicolumn{2}{c}{ Agreement } & \multicolumn{2}{c}{ No opinion } \\
& Number & \% & Number & \% & Number & \% \\
\hline A1 (cancel trip) & 127 & $72.6 \%$ & 41 & $22.3 \%$ & 9 & $5.1 \%$ \\
B1 (leave coastal area) & 117 & $66.9 \%$ & 57 & $32.6 \%$ & 1 & $0.6 \%$ \\
B2 (storm watching) & 92 & $52.6 \%$ & 78 & $44.6 \%$ & 5 & $2.9 \%$ \\
\hline
\end{tabular}

Table 5 shows that about two third of the respondents are rather persistent in their holiday plans. The effect of "storm watching" may contribute to this attitude. However, it should be acknowledged here that possible bias may occur due to the overrepresentation of male respondents in the sample. As previous studies have demonstrated (Ho et al. 2008; Lindell and Hwang 2008; Kellens et al. 2011), men exhibit on average lower levels of risk perception than women. This lower risk perception often results in higher risk-taking behaviour (Jonkman and Vrijling 2008). A second reflection deals with the uncertain correspondence between a person's stated intentions in a questionnaire, and his/her actual behaviour in case a major storm would be forecasted at the coast (cf. Kievik and Gutteling 2011). Despite these limitations, the survey results provide reasonable grounds to assume that a fair 
part of the residential tourists will be present in the coastal area at the time a heavy storm reaches the coastline.

\section{Discussion and conclusion}

In this paper, we have substantiated the inclusion of residential coastal tourism and its dynamics in societal flood risk, which is determined by the number of people at risk and the number of casualties expected in case of flooding. A case study was conducted on the Belgian coast, a densely populated area characterized by a large tourism industry and a high vulnerability toward coastal flooding. A worst case flood scenario was employed to analyze the effects of coastal tourism on casualty computations. The question as to what extent do tourism dynamics affect coastal flood risks shaped the main research objective of this chapter. An additional research objective dealt with the behaviour of these residential tourists in different storm scenarios.

The main research objective was addressed in two steps. Firstly, tourism dynamics were mapped out through a set of time-scaled scenarios based on day-to-day variations (weekday, weekend day or holiday) and seasonal fluctuations. Raw data reflected the occupancy rate of second residences (private dwellings with recreational purposes), from which the number of residential tourists $\left(N_{R T}\right)$ could be determined. Significant differences were observed between the summer half year and the winter half year, as well as on the level of day of week and holidays. While we have made comparisons between different time settings, we were unable to consider peak occupancies. For example, nearly $70 \%$ of the second residences is occupied during weekends in the summer holidays (July-August), but the actual occupancy can easily run up to more than $80 \%$ in the week of the National holiday $\left(\mathrm{July} 21^{\text {st }}\right.$ ). In winter, the average occupancy of second residences varies between $10 \%$ and $40 \%$, yet peak occupancies of more than 50\% are not impossible either (Gunst et al. 2008). Secondly, the number of people at risk and the number of casualties in case of a flooding were determined. It was shown that the number of people at risk $\left(N_{P A R}\right)$ in the summer is twice as large than if only the registered population $N_{P O P}$ is taken. In winter, $N_{P A R}$ is almost $30 \%$ more than if only $N_{P O P}$ is used. As mentioned earlier, these outcomes are average estimations. Peak occupancies can inflate $N_{P A R}$ considerably. Casualty calculations were conducted for a worst case scenario (in which all second residences are supposed occupied) and two time-scaled scenarios (mean tourist number on a summer and a winter day). A worst case flood scenario (CLIMAR WCS 2040) served as flood model within the Flemish GIS tool LATIS, which uses water depth, flow velocity and rise velocity as mortality parameters. This flood scenario is expected to cause numerous dike breaches on the Belgian coast, and will particularly affect three locations: Oostende, Wenduine and De Panne. Especially in Oostende, marked spatial differences were observed between the location of the casualties among the registered population and among the residential tourists. Whereas the former group is mostly situated in the centre of the flooded city, the latter group is particularly located in those sectors adjacent to the coastline. The main cause of this distinction may be the urban morphology of the Belgian coast, which is characterized by high percentages of second residences near the coastline and lower percentages in the centres of the municipalities.

An important note concerns the relative frequency of extreme storm surges. We recall that on the Belgian coast, according to preliminary POT-analyses, the probability of a winter storm is about five times larger than a summer storm. While these frequencies do not affect the casualty calculations reported above, they do affect the corresponding risk values. Hence, in terms of risks, winter casualties should receive a weight factor of 5 in order to meaningfully compare them with summer casualties (which would then receive weight factor of 1).

Concerning the second research objective, qualitative interpretation of survey data suggested that residential tourists are rather persistent in their holiday plans, irrespective of storm forecasting. Moreover, several tourists indicate that they would go to the sea just to watch the storm surge, an outcome which supports previous studies on "storm watching" behaviour (Cantillon et al. 1999). This risk-taking behaviour was even recently observed on the Belgian coast during the severe storm of 
February $28^{\text {th }}, 2010$. Without knowing the consequences of the storm in France (where more than 50 people died in coastal floods), dozens of people visited the Belgian coast. They explained to the media that they were looking for "nature power". Based on the results of the questionnaire, we believe that a significant part of the residential tourists - about two third - will be present at the coastline in case a flood occurs. However, possible survey biases with regard to sample representativeness (overrepresentation of men) and unknown correspondence between intentions and actual behaviour yield uncertainty in this outcome. Future research could lower these uncertainties by employing an experimental study design in which more items are used to measure respondent's intentions.

Some general limitations of the study need to be addressed. A first limitation concerns the level of detail of the census data. Although this data set has a fairly high degree of temporal detail (the occupancy of second residences is known for each day for the period of one year), the spatial resolution is limited to the scale of the entire coastal area. It was therefore not possible to consider spatial variations within the municipalities over time. Other data sets, such as mobile positioning data obtained via GPS devices and mobile phones, might meet this detail level. Recently, several researchers have explored the possibilities of these data sets, for example Ahas et al. (2008), Song et al. (2010) and Byon et al. (2009). In Belgium, as in many other countries, mobile positioning has already been used successfully to track vehicles and estimate traffic jams. However, in Belgium, the data is not yet available for accurately tracking the position of individuals who are not travelling within transport networks (e.g. in buildings, parks, etc.). A second limitation is the assumption of a constant $N_{P O P}$. The registered population mainly fluctuates at the level of day and week as a consequence of inter alia work and leisure activities (Lentz 2006). Previous research on natural disasters and technical hazards proposed ways to determine these $N_{P O P}$ fluctuations (Glickman 1986; Aboelata and Bowles 2005; Ahola et al. 2007), though applying these methods often remains difficult. For instance, in the context of flood risks due to dam failure, McClelland and Bowles (2000) have suggested to consider temporal aspects for a number of homogeneous population groups, such as motorists, train passengers, people living in buildings, etc. However, while valuable at the conceptual level, these refinements become compromised when greater generalizability is desired. A third limitation that should be addressed in future research is the neglect of the effects of evacuation possibilities on population dynamics. Evacuation is defined by the movement of people from a (potentially) exposed area to a safe location outside the area before they come into contact with physical effects (Jonkman et al. 2008). While evacuation models have been developed for floods (e.g., LIFESim - Aboelata and Bowles 2005; Evacuation Calculator - Van Zuilekom et al. 2005), they are difficult to apply in real-world situations given the severe data requirements. Assessing evacuation in flood risk management encompasses the determination of several parameters, such as available time, time required for evacuation, population characteristics (e.g. age, mobility) and road network characteristics (e.g. road density, road capacity, congestion points).

Despite these limitations, the outcomes of this study have clearly foregrounded the implications of accounting for coastal tourism dynamics in flood risk calculations. However, the question remains to what extent the increased insights that can be obtained by the incorporation of tourism dynamics justifies the extra data requirements and computational efforts? If the flood prone area is as touristy as the Belgian coast, it may certainly be justified. This study showed significant temporal variations in coastal tourism dynamics leading to important impacts on coastal flood risk calculations. However, our research did not only result in improved casualty calculations. It also pointed out that there is a spatial, temporal and behavioural vulnerability of coastal tourism towards floods. From a spatial point of view, coastline areas tend to be most vulnerable to storm surges such as overtopping water and dike breaching, given that the majority of the tourists reside nearby the coastline. Temporal variations in tourism can cause peak moments which make tourists extra vulnerable to flooding. Third is vulnerability induced by behaviour during storm surges. A major part of the tourists is not frightened by bad weather and may consequently reside on the coast at the time a flood happens. Although effects may differ between coastal areas, we believe that flood risk management should always verify possible tourism effects. Moreover, the study of tourism dynamics should not be restricted to coastal flood risks. Since mountainous areas are also attractive to tourists, considering tourism dynamics in mountain flash floods could be important as well. Taken together, we hope that our study will 
stimulate a more careful consideration of the implications of tourism dynamics in flood risk management.

\section{Acknowledgments}

Financial support for this work was granted by the Research Foundation - Flanders. The authors further acknowledge the aid of Flanders Hydraulics Research (Flemish Authorities).

\section{References}

Aboelata M, Bowles DS (2005). LIFESim: A Model for Estimating Dam Failure Life Loss. Report to Institute for Water Resources, US Army Corps of Engineers and Australian National Committee on Large Dams by Institute for Dam Safety Risk Management, Utah State University, Logan, Utah

Ahas R, Aasa A, Mark U, Pae T, Kull A (2007) Seasonal tourism spaces in Estonia: Case study with mobile positioning data. Tourism Management 28:898-910

Ahas R, Aasa A, Roose A, Mark U, Silm S (2008) Evaluating passive mobile positioning data for tourism surveys: An Estonian case study. Tourism Management 29:469-486

Ahola T, Virrantaus K, Krisp JM, Hunter GJ (2007) A spatio-temporal population model to support risk assessment and damage analysis for decision-making. International Journal of Geographical Information Science 21:935-953

Bellan GL, Bellan-Santini DR (2001) A review of littoral tourism, sport and leisure activities: consequences on marine flora and fauna. Aquatic Conservation-Marine and Freshwater Ecosystems 11:325-333

Braun OL, Lohmann M, Maksimovic O, Meyer M, Merkovic A, Messerschmidt E, Riedel A, Turner M (1999) Potential impact of climate change effects on preferences for tourism destinations. A psychological pilot study. Climate Research 11:247-254

Burak S, Dogan E, Gazioglu C (2004) Impact of urbanization and tourism on coastal environment. Ocean \& Coastal Management 47:515-527

Burby RJ, Wagner F (1996) Protecting tourists from death and injury in coastal storms. Disasters 20:49-60

Butler RW (1994). Seasonality in tourism: Issues and problems. Tourism: The state of the art. A. V. Seaton. Chichester, England, Wiley: 332-339

Byon YJ, Abdulhai B, Shalaby A (2009) Real-Time Transportation Mode Detection via Tracking Global Positioning System Mobile Devices. Journal of Intelligent Transportation Systems 13:161-170

Cantillon H, Merriam J, Naughton C (1999) Storm chasing: Risk recreation for the nineties. Proceedings of the 1999 Northeastern Recreation Research Symposium:397-399

Charlier RH, Demeyer CP (1995) New Developments on Coastal Protection Along the Belgian Coast. Journal of Coastal Research 11:1287-1293

Deckers P, Kellens W, Reyns J, Vanneuville W, De Maeyer P (2010). A GIS for Flood Risk Management in Flanders. Geospatial Techniques in Urban Hazard and Disaster Analysis. P. S. Showalter and Y. Lu, Springer-Verlag: 51-69

Faulkner B (2001) Towards a framework for tourism disaster management. Tourism Management 22:135-147

Glickman TS (1986) A Methodology for Estimating Time-of-Day Variations in the Size of a Population Exposed to Risk. Risk Analysis 6:317-324

Gunst C, Vandenbroucke L, Verhaeghe A (2008) Tweede verblijven in breedbeeld. West-Vlaanderen Werkt 3:14-21

Hall CM (2001) Trends in ocean and coastal tourism: the end of the last frontier? Ocean \& Coastal Management 44:601-618

Hartman R (1986) Tourism, seasonality and social change. Leisure Studies 5:25-33

Higham J, Hinch T (2002) Tourism, sport and seasons: the challenges and potential of overcoming seasonality in the sport and tourism sectors. Tourism Management 23:175-185 
Ho MC, Shaw D, Lin SY, Chiu YC (2008) How do disaster characteristics influence risk perception? Risk Analysis 28:635-643

Jonkman SN (2005) Global perspectives on loss of human life caused by floods. Natural Hazards 34:151-175

Jonkman SN (2007). Loss of life estimation in flood risk assessment - theory and applications, Delft University. Phd: 354

Jonkman SN, van Gelder P, Vrijling JK (2003) An overview of quantitative risk measures for loss of life and economic damage. Journal of Hazardous Materials 99:1-30

Jonkman SN, Vrijling JK (2008) Loss of Life due to Floods. Journal of Flood Risk Management 1:4356

Jonkman SN, Vrijling JK, Vrouwenvelder ACWM (2008) Methods for the estimation of loss of life due to floods: a literature review and a proposal for a new method. Natural Hazards 46:353389

Kellens W, Zaalberg R, Neutens T, Vanneuville W, De Maeyer P (2011) An Analysis of the Public Perception of Flood Risk on the Belgian Coast. Risk Analysis 31:1055-1068

Kievik M, Gutteling J (2011) Yes, we can: motivate Dutch citizens to engage in self-protective behavior with regard to flood risks. Natural Hazards in press

Lebbe L, Van Meir N, Viaene P (2008) Potential implications of sea-level rise for Belgium. Journal of Coastal Research 24:358-366

Lentz A (2006). Acceptability of Civil Engineering Decisions Involving Human Consequences. Fakultät für Bauingenieur- und Vermessungswesen. München, Technischen Universität München. PhD: 157

Lentz A, Rackwitz R (2004). Loss-of-Life Modelling in Risk Acceptance Criteria. Proceedings PSAM7 - ESREL '04, Berlin, Springer-Verlag

Lindell MK, Hwang SN (2008) Households' perceived personal risk and responses in a multihazard environment. Risk Analysis 28:539-556

Mathijsen A (2003). Verblijftijdentabel voor kwetsbare en beperkt kwetsbare objecten (in Dutch). Bilthoven, RIVM report 620100001/2003: $16 \mathrm{p}$.

McClelland DM, Bowles DS (2000) Estimating life loss for dam safety and risk assessment: Lessons from case histories. Dam O\&M Issues - the Challenge of the 21st Century:473-496

McPherson T, Ivey A, Brown M, Streit G (2004). Determination of the spatial and temporal distribution of population for air toxics exposure assessments. 5th Conference on Urban Environment, Vancouver, Canada

McRobie A, Spencer T, Gerritsen H (2005) The big flood: North Sea storm surge. Philosophical Transactions of the Royal Society A 363:1263-1270

Mertens T, Verwaest T, Delgado R, Trouw K, De Nocker L (2010). Coastal Management and Disaster Planning on the Basis of Flood Risk Calculations. Proceedings of Coastal Engineering 2010, Shanghai, China

Miller ML (1993) The Rise of Coastal and Marine Tourism. Ocean \& Coastal Management 20:181199

Ponsar S, Ozer J, Van den Eynde D (2007). Impacts of climate change on the physical and chemical parameters of the North Sea (literature study). Management Unit of the North Sea Mathematical Models. Brussels: 70

Reyns J, Verwaest T, Mostaert F (2010). Benefits of heightening the sand banks in front of the Belgian coastline for coastal safety. WL Technical Papers, 38. Flanders Hydraulics Research. Antwerp, Belgium

Song CM, Qu ZH, Blumm N, Barabasi AL (2010) Limits of Predictability in Human Mobility. Science 327:1018-1021

Van der Biest K, Verwaest T, Reyns J (2008). Assessing climate change impacts on flooding risks in the Belgian coastal zone. LITTORAL 2008. A Changing Coast: Challenge for the Environmental Policies, Venice, Italy

Van Zuilekom KM, van Maarsseveen MFAM, van der Doef MR (2005). A decision support system for preventive evacuation of people. The First International Symposium on Geo-information for Disaster Management, Delft, the Netherlands, Springer-Verlag 
Vanneuville W, Maddens R, Collard C, Bogaert P, De Maeyer P, Antrop M (2006). Impact op mens en economie t.g.v. overstromingen bekeken in het licht van wijzigende hydraulische condities, omgevingsfactoren en klimatologische omstandigheden. F. E. A. MIRA, UGent 